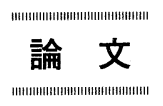

\author{
石炭液化アスファルテンの水添特性 \\ (キーワード 石炭液化, アスファルテン, オイル, 水素化反応, 反応機構, 水素移動, 水素消費量) \\ -1990.6 .21 受理一
}

北海道大学 永石博志, 松尾 匡, 中畑拓治, 小西寛昭 守富 寛, 真田雄三, 千葉忠俊

\section{1. 緒 言}

石炭液化プロセスの予熱器抒よび反応器の設計やプ ロセスを円滑に操作するには, 液化反応特性を知る必 要があり,これには液化反応特性の定量的な取扱いが 不可欠である。そのため，これまで多くの反応モデル が提出されているが，そのほとんどが液化生成物をそ の溶媒への溶解性の差を利用して分別する方法に基づ いている ${ }^{1)}$ 。この溶剤分別法は莫大な数の化学種が関 与している液化反応を巨視的に整理することを目的と しており, 多くの場合液化生成物中のピリジン不溶成 分を未反応石炭, ピリジン可溶一ベンゼン不溶成分を プレアスファルテン, ベンゼン可溶一ヘキサン不溶成 分をアスファルテン，へキサン可溶成分をオイルなど と分別する。これにより石炭や中間生成物などの速度 論的特性がかなり明確になってきているが2) 4), 反 応器からの液化生成物の蒸留分離や液化油のアップグ レーディングなどの操作を考えるとこれだけでは不十 分である。すなわち, これらの操作のためには，ほと んどの反応モデルに抏いて最終生成物として一つの成 分にランピングされているオイル成分の化合物分布を, 例えば蒸留分別法 ${ }^{5)}$ に基づいた沸点分布などによって 表示したほうが都合がよい。ところが，このような観 点からアスファルテンからオイルへの, またオイル自 身あるいはオイルからガスへの水添低分子化反応特性 を詳細に検討した研究はきわめて少な( ${ }^{5)}$ ７)のが現 状である。

本論文では, アスファルテンや SRC-II プロセスオ イルを反応物として液化反応を行い, 生成物をまず溶 剤分別して, 得られたオイル成分をさらに蒸留分別に

工学部金属化学研究施設 札幌市北区北13条西 8 丁目
よりほぼ芳香環数を反映した 4 つの沸点成分に細分別 して, これらの成分の生成に伴う水素消費量を求め, 反応機構について考察した結果を報告する。

\section{2. 実験方法}

2.1 試 料

反応試料として用いたアスファルテンは, $100 \mathrm{mesh}$ 以下に粉砕した $100 \mathrm{~g}$ の赤平炭を内容積 $500 \mathrm{~cm}^{3}$ の振盪式 オートクレーブ中で $150 \mathrm{~g}$ のテトラリンと $723 \mathrm{~K} て ゙ 30$ 分 間反応させて得た。このときの水素初圧は $10.1 \mathrm{MPa}$, 昇温および冷却速度はそれぞれ 4 〜 K/min および 20 〜30K/min とした。反応後の内容物は十分量のベンゼ ンおよびへキサンでそれぞれ 3 時間おのおのの溶媒の 沸点で煮沸抽出 ${ }^{3) 8}$ ()

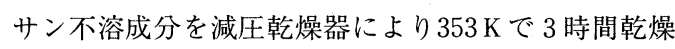
したものをアスファルテン試料とした。また，オイル 試料には，SRC-IIプロセスから得られたイリノイ炭 液化油のへキサン可溶成分を用いた。赤平炭, アス ファルテンおよびオイルの元素分析值を Table 1 に示 す。

溶媒には水素供与性の高いテトラリンを用い, 触媒 には工業用 $\mathrm{Co}_{0}-\mathrm{Mo}^{-} \mathrm{Al}_{2} \mathrm{O}_{3}$ (Cyanamid 社製) を予備硫

Table 1 Ultimate analysis of materials used

\begin{tabular}{lccccc}
\hline Materials & $\mathrm{C}$ & $\mathrm{H}$ & $\mathrm{N}$ & $\mathrm{S}$ & $\mathrm{O}^{(1)}$ \\
\hline Akabira coal & 80.20 & 6.15 & 1.58 & 0.72 & 11.35 \\
Asphaltene from & 86.09 & 5.77 & 2.75 & 0.36 & 5.03 \\
Akabira coal & & & & \\
SRC- II oil & 89.27 & 7.86 & 0.78 & $2.02^{(2)}$ \\
\hline
\end{tabular}

(1) By difference

(2) $\mathrm{O}+\mathrm{S}$ by difference 
化処理をせずに100mesh 以下に粉砕して用いた。

\section{2 実験装置}

反応器には内容積か $555 \mathrm{~cm}^{3}$ の電磁擋拌式オートクレー ブ3)を用いた。これには $250 \mathrm{~cm}^{3} の$ 圧力緩衝容器を連結 してあり，加熱，冷却打よび反応中の圧力変化を無視 できるようになっている。加熱と冷却には扔の扔の赤 外線イメージ炬および圧搾空気を用い, 昇温㧍よび降 温速度を $150 \mathrm{~K} / \mathrm{min}$ 抢よび $100 \mathrm{~K} / \mathrm{min}$ に制御した。

\section{3 実験方法}

反応器には, アスファルテンあるいはオイル試料 $5 \mathrm{~g}$ と触媒を用いるときは触媒 $0.5 \mathrm{~g}$ を充填した。ま た，溶媒を用いるときには $3 \mathrm{~g}$ の反応試料に対し $5 \mathrm{~g}$ のテトラリンを用いた。各実験では反応器内を水素ま たは窒素で置換して $10.1 \mathrm{MPa}$ に昇圧後, 反応器を上 記の昇温速度で加熱し， $723 \mathrm{~K}$ の温度を所定反応時間 保持してから冷却した。冷却後の反応器内容物は, ま ずベンゼン，へキサンおよびピリジンでおのおの 3 時 間順次煮沸抽出し, ヘキサン可溶成分（以下，O と略 記), ベンゼン可溶一ヘキサン不溶成分（同 A）, ピリ ジン可溶一ベンゼン不溶成分 (同 PS-BI) 抄よびピリ ジン不溶成分（同 PI）に分別した。得られたへキサ ン可溶成分 (O) については, さらに $5 \%$ OV-1を chromosorb W に担持した充填カラムを装着した島津 石油留分沸点測定システムを用い, $303 \mathrm{~K}$ から $623 \mathrm{~K}$ ま で, $8 \mathrm{~K} / \mathrm{min}$ の速度で昇温分析して，その沸点分布を 求めた ${ }^{9)}$ 。また, 反応後の溶媒組成は, キャピラリー カラム SE-52 FS-WCOT を装着した日立163形ガスク ロマトグラフにより， $\alpha$-メチルナフタレンを内部標 準物質として初期温度 $373 \mathrm{~K}$ から $538 \mathrm{~K}$ まで $3 \mathrm{~K} / \mathrm{min}$ で昇温して測定した。

\section{3. 結果と考察}

\section{1 反応モデル}

Fig. 1 にアスファルテンを溶媒と触媒を用いずに水 添して得られたへキサン可溶成分の沸点分布曲線を例 示する。図から，468K から $498 \mathrm{~K}$ 付近に留出量の多い 成分がみられる。いま，多環芳香族類の沸点が縮合環

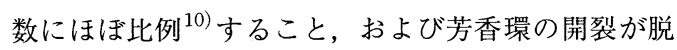
アルキル反応に比べて起こりにくいことを考慮して, このような分布曲線が図中の化合物を主骨格構造にも つ化合物からのアルキル基等の脱離により得られたと 考えると, これらの化合物集団をつぎのような 4 つの オイル成分と定義することができる。すなわち，ここ では,

$468 \mathrm{~K}$ 以下の留分 $O_{1}$ (一環相当化合物)

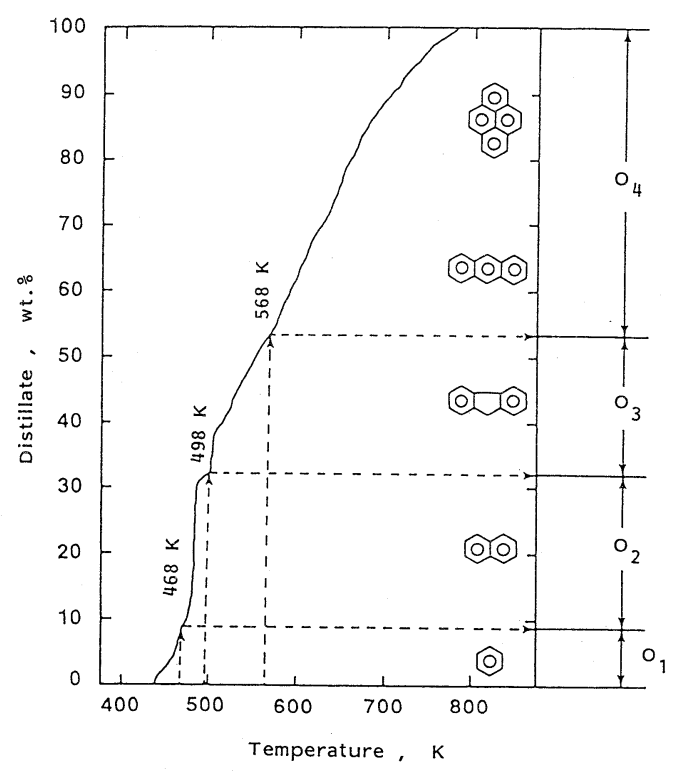

Fig. 1 Typical boiling-point temperature distribution of oil from asphaltene hydrogenation under $10.1 \mathrm{MPa}$ of hydrogen without solvent and catalyst at $723 \mathrm{~K}$

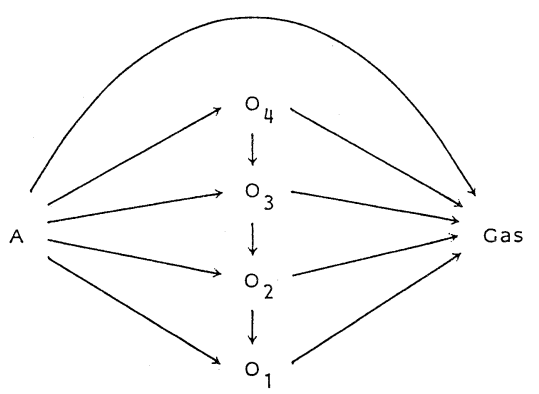

Fig. 2 Possible reaction paths from asphaltene to four oil fractions

468-498K の留分 $\mathrm{O}_{2}$ (二環相当化合物)

498-568K の留分 $\mathrm{O}_{3}$ (フルオレン型二環相当化合物) $568 \mathrm{~K}$ 以上の留分 $\mathrm{O}_{4}$ (三，四環以上相当化合物)

とする。

このようにオイル成分をわずか 4 つの成分に分別し て表しても，アスファルテンからこれらオイル成分へ の生成経路は, Fig. 2のように複雑なものとなる。こ のままでは速度定数を一義的に決定できないばかりで なく反応特性を支配するパラメーターの感度も検討で きない。そこで, 反応特性を表すために必要最小限の 反応経路の検討を以下のように行った。 
アスファルテンを触媒を用いずに水素雲囲気下で反 応させたときの生成物収率の経時変化を Fig. 3 に示 す。この場合には, アスファルテンの重質成分やオイ ル成分への転化反応速度は, 石炭の転化反応速度に比 べてきわめて緩慢 ${ }^{2}$ であり，PS-BIやPI 成分への重

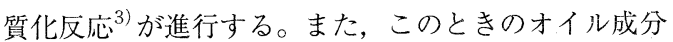
収率は反応の初期段階からほぼ一定であり， $\mathrm{O}_{4}$ とガス の収率だけが漸増している。これに対し，この系に触 媒を添加した場合には，Fig. 4 に示すように，重合反 応は抑制され，オイル成分の収率は時間とともに単調

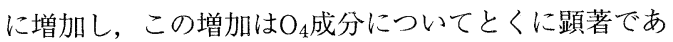
る。アスファルテンの低分子化反応において，Fig. 2 に示したすべての反応経路が同等に寄与すれば，触媒

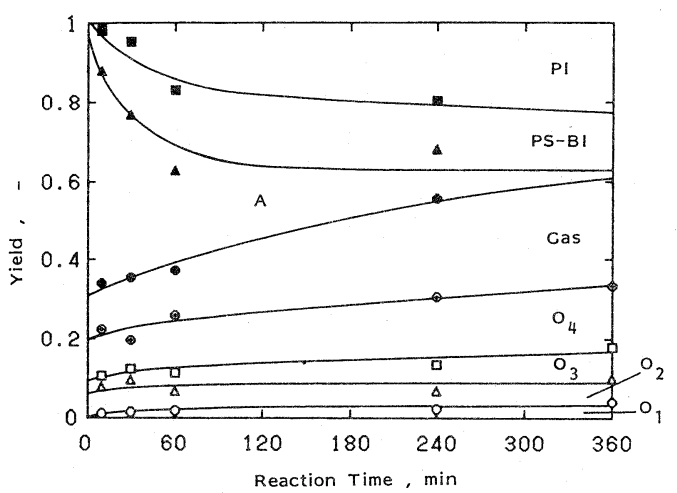

Fig. 3 Time profiles of yields of products from asphaltene hydrogenation under $10.1 \mathrm{MPa}$ of hydrogen at $723 \mathrm{~K}$ without solvent and catalyst

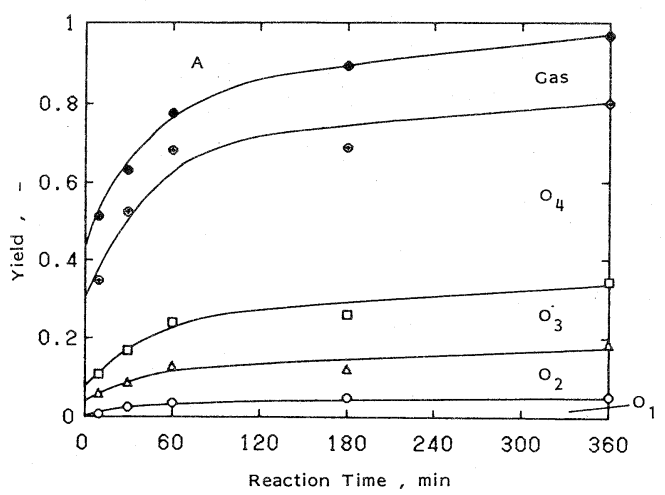

Fig. 4 Time profiles of yields of products from asphaltene hydrogenation under 10.1 MPa of hydrogen at $723 \mathrm{~K}$ in the presence of Co-Mo- $\mathrm{Al}_{2} \mathrm{O}_{3}$ catalyst
を添加した場合にはオイル成分ばかりでなくガスの生 成も促進されるはずであるが，ガス収率は触媒を添加 しない場合と大差がない。この結果はアスファルテン から直接ガスを生成する経路に対する触媒の寄与が非 常に小さいことを意味する。また，Fig. 5(a)および(b) は，このような収率変化に対応したガスとオイル成分 の組成変化を示したものである。これをみると, 組成 が時間とともに変化していることから，オイル成分か らガスへの反応経路を考慮する必要があることがわか る。また，この触媒はアスファルテンからの $\mathrm{O}_{4}$ 成分 の生成を選択的に促進するといえる。さらに，このよ うに触媒の添加により $\mathrm{O}_{4}$ 成分生成反応が加速され, 系内の $\mathrm{O}_{4}$ 成分濃度が高くなるにもかかわらず，ガス 生成量が触媒を添加しないときと変わらないことを速 度論的に説明するには， $O_{4}$ 成分からガスへの反応速

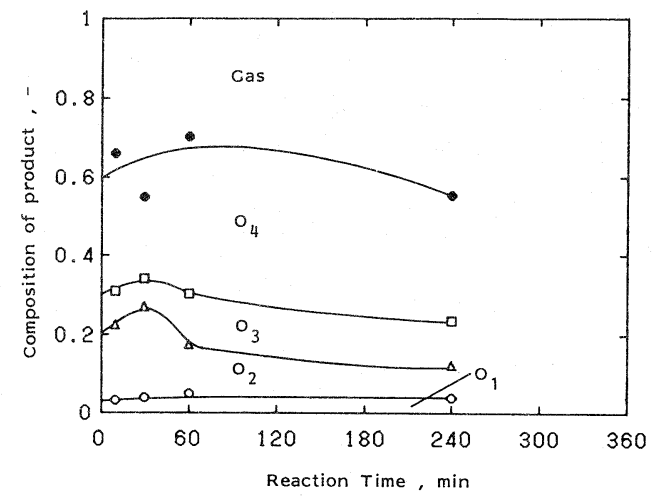

(a)

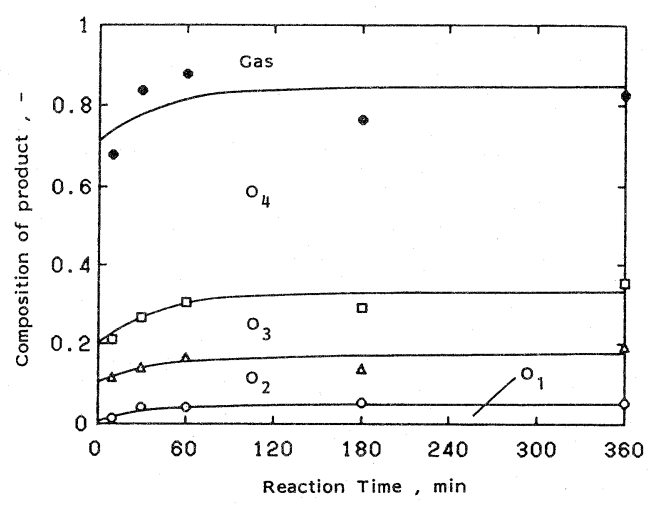

(b)

Fig. 5 Time profiles of distribution of gas and oil fractions: Reaction system; (a) asphaltene and hydrogen gas, and (b) asphaltene, hydrogen gas and $\mathrm{Co}-\mathrm{Mo}-\mathrm{Al}_{2} \mathrm{O}_{3}$ catalyst 
度が触媒を添加しないときに比べて相対的に小さいと 考えなくてはならない。すなわち，オイル成分からの ガス生成反応が主にナフテン環の開裂やアルキル側鎖 の脱離に起因するものであるとすれば，単位質量当り のオイル成分中のこれらの化学構造をもつ分子の数は 分子量に反比例寸るので, $\mathrm{O}_{1}$ から $\mathrm{O}_{4}$ 成分へと分子量 が大きくなるほど，オイル成分からガスへの反応速度 は小さいものと考えなければならない。

次に, SRC-IIのオイル成分（初期組成：90 wt $\% \mathrm{O}_{4}$ および $\left.10 \mathrm{wt} \% \mathrm{O}_{3}\right)$ と,これを触媒を用いて異なった 時間水添反応させたときの生成物の沸点分布曲線を Fig. 6 に示す。罒から，反応による SRC-IIオイル成 分の軽質化は明らかであるが，反応時間が 60 分と 120 分の分布曲線には有意差はみられない。また，両場合 とも $\mathrm{O}_{1}$ や $\mathrm{O}_{2}$ 成分の生成はほとんどみられない。し たがって， $\mathrm{O}_{4}$ から $\mathrm{O}_{1} や \mathrm{O}_{2}$ 成分一と逐次低分子化す る経路は，とくに考慮しなくともよいと考えられる。

以上のことから，アスファルテンの水添低分子化反 応は，Fig. 7 のように単純化して考えることができる。

\section{2 水素移動機構}

アスファルテンを水添するときの水素としては，ア スファルテン内の水素, 気相水素, 抢上び溶媒 ${ }^{* 1}$ が

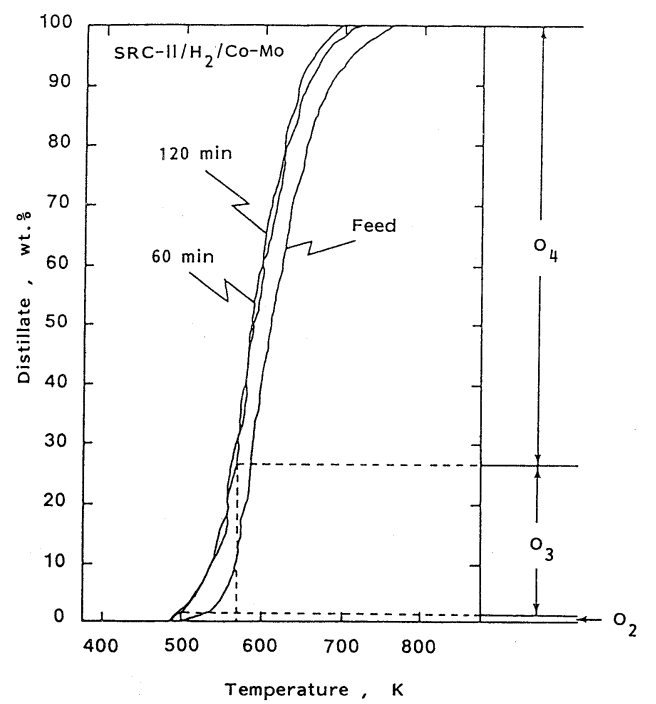

Fig. 6 Boiling-point temperature distrıbutions of products from SRC-II oil hydrogenation by hydrogen gas in the presence of catalyst for different duration

*1一般に, アスファルテン以外の溶媒分子で, こ こでは扔もにテトラリンを指す。

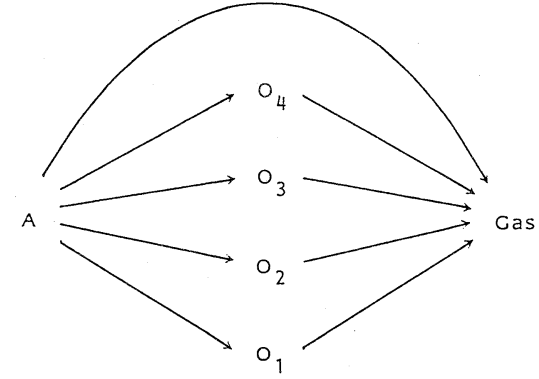

Fig. 7 A reaction model for comprehensive explanation of the present experimental results

考えられる8)。アスファルテンの分子内水素移動によ る低分子化を調べるために，まず気相を窒素とし，溶 媒を用いずにアスファルテンを反応させたが，アス ファルテン以外からの水素供給を断った場合には，才 イル成分は全く生成せず，不均化により PI と PS-BI 成分が急激に生成するだけであった。この結果は，ア スファルテンの熱分解反応が迅速であると同時に，水 添低分子化反応には気相や溶媒からの外部水素の供給 が不可欠であることを示唆している。そこで，アス ファルテンの水添低分子化反応に及ぼす外部水素の効 果を検討するために，気相は窒素のままでテトラリン を溶媒に用いて反応を行った結果がFig. 8である。 気相の水素を水素源と想定した Fig. 3 と比較すると, 溶媒を水素源としたこの場合には重質成分とガスの生 成が抑制され，オイル成分の収率が高くなっている。 この結果は，石炭の水添液化の場合にはテトラリンは, 石炭と同量以上用いれば石炭の転化率はガス種や触媒

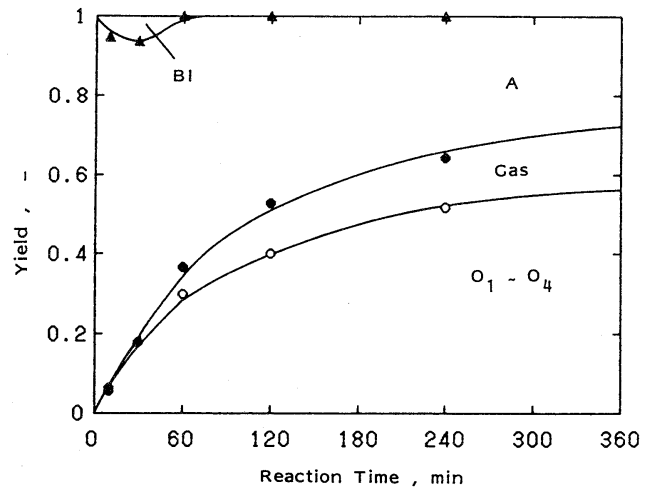

Fig. 8 Distribution of products from asphaltene hydrogenated by tetralin under nitrogen without catalyst at $723 \mathrm{~K}$ 
の有無によらなくなるほど十分の水素供給能を示す ${ }^{10)}$ が，これがアスファルテンの水添に対しても有効であ ることを示している。さらに，ここでは省略したが， この反応系に触媒を加えてもアスファルテンの転化率 は変化せず，ガス収率だけが高くなった。窒素／テト ラリン系に対するこれらの触媒添加効果の結果と Fig. 3 およびFig. 4 の結果を考えあわせると，石炭 よりもはるかに軽質なアスファルテンの水添の場合に は，触媒は気相からの水素移動を促進するが，テトラ リンからアスファルテンへの水素移動にはほとんど寄 与しないといえる。このように石炭よりも軽質な成分 の水添には, 気相からの水素移動が触媒の存在によっ て顕著になることがわかる。Fig.9(a)および(b)は，上 記条件下の未反応アスファルテン収率の経時変化をま とめて片対数で示したものである。気相が水素のとき には，見かけ反応時間 0 分で約 $40 \%$ のアスファルテン

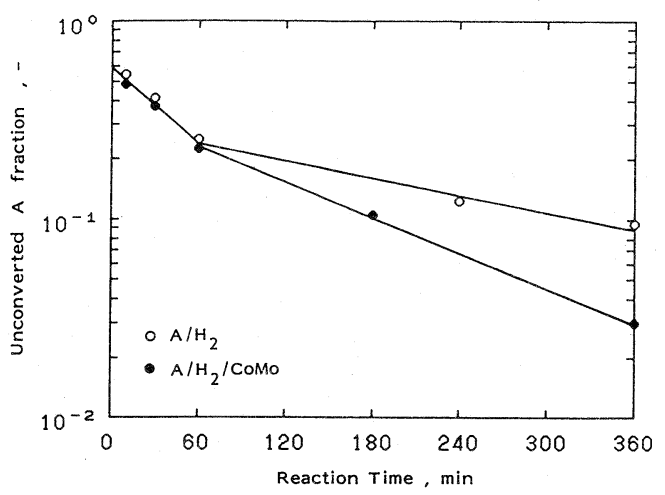

(a)

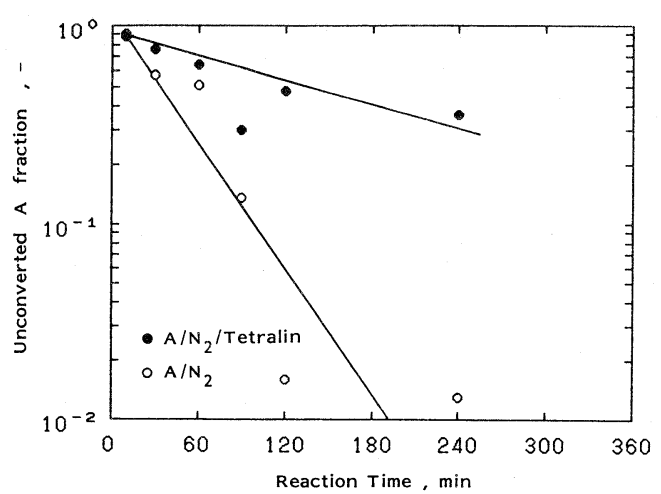

(b)

Fig. 9 Semi-logarithmic plots of unconverted asphaltene fraction obtained (a) under hydrogen with or without catalyst, and (b) under nitrogen with or without solvent
が転化している。また，反応時間60分までの初期段階 では直線関係が得られ，この領域では未反応アスファ ルテンの反応性が一定であるとみなせるが，180分以 降の後期では反応速度が大きく変わっていることから 未反応アスファルテンの反応性は徐々に変化している ことがわかる。この変化割合は触媒の有無によって異 なり, これは水添反応に伴う化学構造の変化に起因し ていると予測できる。アスファルテンは溶媒抽出に よって定義された混合物であるが，アスファルテンが 数個の芳香族縮合環が架橋結合等によって集合した平 均化学構造をもつと考えると, 昇温過程で芳香環の水 素化が開始し, 反応温度付近で架橋および環の開裂が 盛んになると思われる。一般に $723 \mathrm{~K}$ の反応条件下で は，芳香環の水素化よりも環の脱水素反応が優勢にな るために，熱によって開裂した環や架橋の安定化にこ の脱水素した水素が消費され, $723 \mathrm{~K}$ 到達後の初期過 程では触媒の有無に大きく影響されることなく転化反 応が進行するものと推測できる。これに対し，気相が 窒素の場合には，溶媒を用いないときの結果からアス ファルテンの熱分解反応が迅速であることは明らかで あるが, 水素供与能が高いといわれるテトラリンを溶 媒にしても昇温中の転化反応はほとんど進行せず, $723 \mathrm{~K}$ に到達後も重質化反応は抑制されるものの，水 添反応の進行は水素の場合に比べて緩慢であることが わかる。これらの結果は, アスファルテンの水添反応 に掞いて，芳香環の水素化反応は環や架橋結合の開裂 に伴う水素化反応に先行し，テトラリンは $723 \mathrm{~K}$ の条 件下では，後者の開裂反応に伴う水素化には有効であ るが, 前者の芳香環の水素化には気相水素ほど有効に は作用しないことを示唆している。

\section{3 水素消費量の推定}

前節で明らかにしたように，アスファルテンの水添 低分子化には気相や溶媒からの水素が必要である。そ こで，水素源をテトラリンに限定して，アスファルテ ンの水素消費量を求めた。まず，本実験条件でテトラ リンだけを加熱した後の溶媒組成を，ガスクロマトグ ラフィにより $\alpha$ ーメチルナフタレンを内部標準物質と して求めた。その結果, $95 \mathrm{wt} \%$ 以上のテトラリンが そのまま残存してナフタレンやデカリンの生成はほと んどみられなかった。すなわち，テトラリンの脱水素 による水素生成とこれの気相への移動は無視できるこ とを確認した。一方，アスファルテンを水添した後の 溶媒はテトラリン，ナフタレンおよびデカリンが大部 分であった。したがって， 


$$
\begin{array}{r}
\mathrm{T} \rightarrow \mathrm{N}+4 \mathrm{H} \\
5 \mathrm{~T} \rightarrow 3 \mathrm{~N}+2 \mathrm{D}
\end{array}
$$

$$
\begin{array}{ll}
\text { T ; テトラリン, } & \mathrm{N} \text {; ナフタレン } \\
\mathrm{D} ; \text { テデカリン } & \mathrm{H} \text {; 水素 }
\end{array}
$$

のような脱水素および不均化反応以外の反応は無視で き,アスファルテン共存下の反応後に生成するナフタ レンはアスファルテンが脱水素反応（(1)式）により生 成する水素を消費したために生成したと考えることが できる。そこで，不均化により生成したナフタレンを 除いて次式にしたがい水素消費量（H）を算出した。

$$
\begin{aligned}
& \mathrm{H}= \mathrm{W}_{\mathrm{T} 0}\left(\frac{\mathrm{f}_{\mathrm{N}}}{128}-\frac{3}{2} \times \frac{\mathrm{f}_{\mathrm{D}}}{138}\right) \times 4 \times 1000 \\
& \mathrm{H} \quad ; \text { 水素消費量 }(\mathrm{mg}) \\
& \mathrm{W}_{\mathrm{T} 0} ; \text { テトラリン初期充填重量 }(\mathrm{g}) \\
& \mathrm{f}_{\mathrm{N}} \quad ; \text { ナフタレン重量分率 }(-) \\
& \mathrm{f}_{\mathrm{D}} \quad ; \text { デカリン重量分率 }(-)
\end{aligned}
$$

このようにして求めた水素消費量から，アスファルテ ン $1 \mathrm{~g}$ 当りに換算した水素消費量を求め, これと生成 物収率の関係を示したのがFig.10である。オイル収

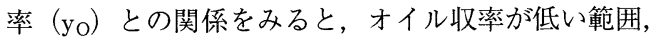
すなわち反応の初期で水素消費量はほぼ直線的に増加 するが，收率が高くなるとともに増加割合が大きくな ることがわかる。Fig. 7 の反応モデルに基づいてこの 結果を考えると, 水素は, 反応の初期段階では括もに オイル生成に消費されるが, 反応の進行とともに生成 したオイルのガス化反応にも消費されるようになるこ

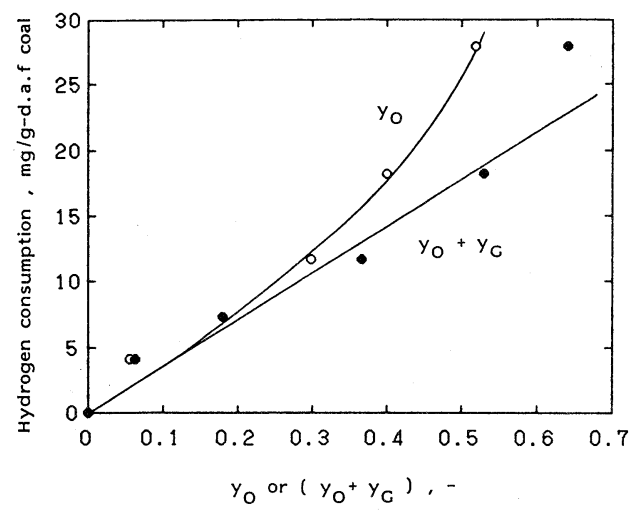

Fig. 10 Hydrogen consumption per unit mass of asphaltene as a function of oil yield ( $\mathrm{y}_{0}$ ) and asphaltene conversion $\left(y_{O}-y_{G}\right)$ under $10.1 \mathrm{MPa}$ of nitrogen with tetralin at $723 \mathrm{~K}$
とを示唆している。そこで，同じ水素消費量をアス ファルテンの転化率（ここでは，オイル収率とガス収 率の和， $\left.\mathrm{y}_{\mathrm{O}}+\mathrm{y}_{\mathrm{G}}\right)$ に対して点緅すると，図のように， 両者の関係は直線関係により表された。

これらの結果は, Fig. 7 に示した反応モデルの妥当 性を確認するものであり，さらに，アスファルテンと 各オイル成分の化学組成は反応が進行してもあまり変 化しないことを示唆している。

\section{4. 結 論}

急速昇温が可能なマイクロオートクレーブを用いて, 赤平炭から得たアスファルテンの水添反応実験を $723 \mathrm{~K}, 10.1 \mathrm{MPa}$ の条件で行い, 生成したオイル成分 を沸点分布に基づいて 4 つの成分 $\left(\mathrm{O}_{1} \sim \mathrm{O}_{4}\right)$ に分別 して, 反応機構，水素移動機構および水素消費量につ いて考察した。その結果，本実験範囲でつぎのことが 明らかになった。

（1）アスファルテンの水添反応特性は，アスファル テンから各オイル成分およびガス成分への並発反 応経路を考えた反応モデルにより説明できる。

（2）テトラリンはアスファルテン水添のための水素 源となる。また, 触媒存在下では気相の水素も有 効な水素源となる。

(3) $\mathrm{Co}-\mathrm{Mo}^{-} \mathrm{Al}_{2} \mathrm{O}_{3}$ はテトラリンからアスファルテン への水素移動には関与しない。

（4）アスファルテンの水素消費量は転化率に比例し て増加する。

\section{文献}

1 ) 千葉忠俊，エネルギー技術データハンドブックー 石炭技術編データ解説版 (第一分冊) 一, エネル ギー総合工学研究所, p.81 (1988)

2 ）千葉忠俊，燃協誌，63，156 (1984)

3 ) Nagaishi, H., Moritomi, H., Sanada, Y. and Chiba, T., Energy Fuels, 2 , 522 (1988)

4 ) Moritomi, H., Deng, C.-R., Nagaishi, H., Shimomura, S., Sanada, Y. and Chiba, T., ibid., 2, 529 (1988)

5 ) Shah, Y.T., Cronauer, D.C., McIIvried, H.G. and Parascos, J.A., Ind. Eng. Chem. Proc. Des. \& Dev., 17, 288 (1978)

6 ) Yoshida, R., Maekawa, Y., Ishii, T. and Takeya, G., Fuel, 55, 337 (1976)

7 ) Szczygiel, J. and Stolarski, M., Fuel, 67, 1292 (1988)

8 ）守富 寛, 永石博志, 成瀬雅彦, 真田雄三, 千葉 忠俊，燃協誌，62，254（1983） 
9 ) Yoshida, R., Hara, S., Ibaragi, S., Narita, H., Sato, M. and Maekawa, Y., Liquid Fuel Tech., 2, 55 (1984)
10) Satou, M., Yokoyama, S. and Sanada, Y., Fuel, 68, 1048 (1989)

\title{
Hydrogenation Characteristics of Akabira Coal Asphaltene
}

\author{
Hiroshi NAGAishi, Tadasu Matsuo, Takuji NAKAHATA, Hiroaki KONISHI, \\ Hiroshi MORITOMI, Yuzo SANADA, and Tadatoshi CHIBA
}

(Metals Research Institute, Hokkaido University)

SYNOPSIS:- Reaction mechanism, hydrogen transfer and consumption of asphaltene hydrogenation were examined at $723 \mathrm{~K}$ and $10.1 \mathrm{MPa}$ of nitrogen or hydrogen with or without solvent and catalyst. The asphaltene was prepared by hydrogenating Akabira coal at $723 \mathrm{~K}$ and $10.1 \mathrm{MPa}$ of hydrogen. The oil products, i. e. the hexane solubles, were fractionated by gas chromatography into four oil components, $\mathrm{O}_{1}$ to $\mathrm{O}_{4}$, having different boiling-point temperature ranges and aromatic ring numbers.

On the basis of the time profiles of the asphaltene conversion and the yields of oil fractions and gas, it was shown that the rate for formation of oil components from the heavier ones was negligibly small so that they could be assumed to be formed independently each other from asphaltene. Asphaltene was easily hydrogenated to oil components by tetralin. In the presence of $\mathrm{Co}-\mathrm{Mo}-\mathrm{Al}_{2} \mathrm{O}_{3}$, only the rate for formation of the heaviest oil component, $\mathrm{O}_{4}$, was accelerated by hydrogen transfer from the gas phase. The hydrogen consumption per unit mass of asphaltene was found to increase in proportion to the asphaltene conversion, implying that reactivity of asphaltene was almost invariable during initial stage of hydrogenation.

\section{Key Words}

Coal liquefaction, Asphaltene, Oil, Hydrogenation, Mechanism, Hydrogen transfer, Hydrogen consumption 